\author{
by Zhifa Yang ${ }^{l}$, Yanjun Shang ${ }^{1 *}$, Lihui Li $^{l}$, Luqing Zhang ${ }^{l}$, Zhongjian Zhang ${ }^{l}$, Tianbin Li ${ }^{2}$, \\ Wei Zhang ${ }^{l}$, Shangshu $\mathrm{Xu}^{3}$
}

\title{
Long-term stability of large span caverns at the 1400-year Heidong quarry
}

\author{
${ }^{1}$ Institute of Geology and Geophysics, Chinese Academy of Sciences, Beijing 100029, China. *E-mail: jun94@mail.igcas.ac.cn \\ ${ }^{2}$ State Key Laboratory of Geohazard Prevention and Geoenvironment Protection (SKLGP), Chengdu University of Technology, Chengdu \\ 610059, China. ${ }^{3}$ Research Committee of Tiantai Mountain, Tiantai 317200, China
}

Long-term stability of large span caverns is earnest but poorly understood in preservation of cultural relics. The life span of huge caverns is difficult to extrapolate from short period of monitoring or laboratory testing. A huge ancient quarry with 21 caverns whose original status is well kept over 1400 years was found in Tiantai County of South China. One of the caverns has an $81 \mathrm{~m}$ span which is far beyond the $50 \mathrm{~m}$ expectation on current knowledge. The tension at the core of long stability is the excavation speed versus deliberation. Here we show a unique technique of Digging Holes for Quarrying Vertical Flagstone (DQF) invented by ancestors to ensure the safety, which is much smarter compared to blasting and casting technique that commonly used after the Industrial Revolution. Furthermore, in addition to selecting competent massive rocks via cutting normally to and through faults, they adopted systematically trial adits, dome-shaped cavern, and disposal of waste rocks inside caverns for support. These ancient achievements mark a high level of quarrying in complex natural conditions with manpower. The results are positive to extend our knowledge in category design of cavern scale and stability assessment, and to some extent, they give solutions to the conflict between fast excavation with blasting and induced excavation damaged zone (EDZ) in surrounding rocks.

\section{Introduction}

Ancient large scale caverns are attractive in multidisciplinary researches such as engineering geology, rock mechanics and archaeology (Wang et al. 1984). Long-term stability of large span caverns is serious but poorly understood in cultural relics preservation (News and Views, 1930). It is difficult to extrapolate the life span of huge caverns from short period of in-situ monitoring or current laboratory tests (Aubertin et al., 2000).

Some ancient quarrying caverns form integral parts of historic sites visited by tourist worldwide, for example, the bell-shaped caverns of Bet Guvrin excavated 1300 years ago in Israel (Tsesarsky et al., 2000; Hatzor et al., 2002; http://en.wikipedia.org/wiki/ Beit_Guvrin_National_Park), the Wieliczka Salt Mine is a world heritage site functioning continuously since the Middle Ages in Poland (Zuber et al., 2000), the Basilica Cistern at Istanbul, Turkey (http:// english.istanbul.gov.tr). In recent years, it has been noted that there are some large scale quarry caverns in Zhejiang Province, South China (Yang et al., 2003). For instance, the Longyou Caverns constructed about 2000 years ago at Longyou (Li et al., 2009), Feifengyan Caverns originated 700 years ago at Xianju (Guo, 2006), Shepan Island Caverns at Sanmen (Zhang, 2010), Panlong Caverns at Huangyan (Yang et al. 2007), and Changyu Caverns at Wenling (Yang et al. 2011). Distribution of these ancient large scale caverns are shown in Fig.1a. Some features of these caverns are listed in Table 1. By comparison, the Heidong quarry cavern is the most famous for its largest span of $81 \mathrm{~m}$ (for its location, see Fig.1).

From the viewpoint of underground engineering design and construction, as well as cultural relics preservation, it is concerned not only the long-term stability, but also as an inspiration to current society (Butzer and Harris, 2007). What's more, analogical analysis of large scale completed engineering projects (Broch et al., 1996) may also contribute to the current modification of specifications or guidlines of risk engineering design.

As one distinctive case example, the Heidong quarry consists of 21 main and 42 secondary caverns, whose original status is well kept for over 1400 years, distributing in an area of about 24,000 $\mathrm{m}^{2}$, and was found under Xieshan Hill, in Tiantai County of South China (Fig.2). This region is famous in eastern Asia as the original center of the Tiantai Sect, one of the Exoteric Buddhism of Mahayana Buddhism. Among the caverns, one reaches unsupported spans of up to $81 \mathrm{~m}$, which is far beyond the $50 \mathrm{~m}$ expectation on current knowledge (SBMI, 2001; Barton, 2002; Hatzor et al., 2010). As an analogical model, Heidong quarry caverns provide an in-situ test at 1:1 scale, which contains precious data hardly to obtain from short period of in-situ monitoring or laboratory tests (Aubertin et al., 2000). It is known that there are five factors that contribute to its abnormal spatial and life spans. (a) The massive rock is generally integrated with optimal engineering geological conditions. (b) Tools such as short iron chisel and hammer were used for manual quarrying. (c) The ancients excavated the cavern as dome roof. (d) They adopted trial adits or pits for trial and error at the port or passing through faults. (e) They stacked waste stones within abutments or on floors for supporting and farmland-saving. 


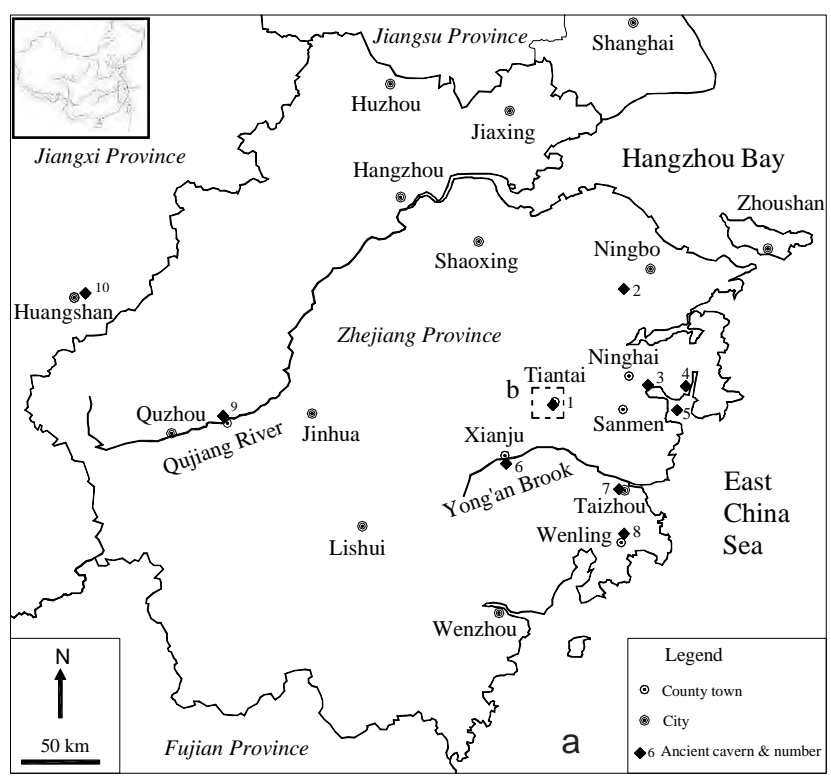

\section{Materials and methods}

Historical records at nearby villages and inscription on stones at temples were used for dating the Heidong quarry. Since the Heidong large scale quarrying is lack of formal literature records in the Tiantai County, we studied textures of written records in memoirs, as well as special geological phenomenon to date its original excavation time.

Field survey and observation method for measurement of engineering geological conditions (including strata, faults, joints and

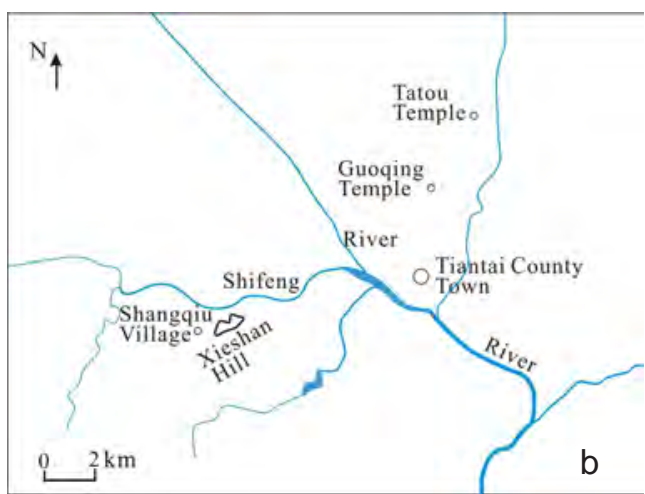

Fig.1 Locations of ancient quarry caverns in SE China. a. Distribution in Zhejiang Province. 1. Heidong qurry, 2. Shanghua Hill quarry, 3. Yishi quarry, 4. Wushan quarry, 6. Feifengyan quarry, 7. Panlongdong quarry, 8. Changyu quarry, 9. Longyou cavern, 10. Huashan cavern. b. Location of the Heidong quarry just in Xieshan Hill as the dark line circle at the southern bank of the Shifeng River, southwest of Tiantai County town.

groundwater) were adopted. By means of the TCA2003 type of Leica total station, we measured the magnitude of caverns.

Polar stereographic projection was used for processing attitudes of discontinuities (faults and joints) measured in the field. Discontinuities affect the aligned layout and appearance of common walls of the cavern.

Massive tuffs are host rocks of quarrying flagstones, and are taken as the subject of this research. Intact rocks of tuff were sampled in the quarrying site. Epoxide resin was used for thin section polishing,

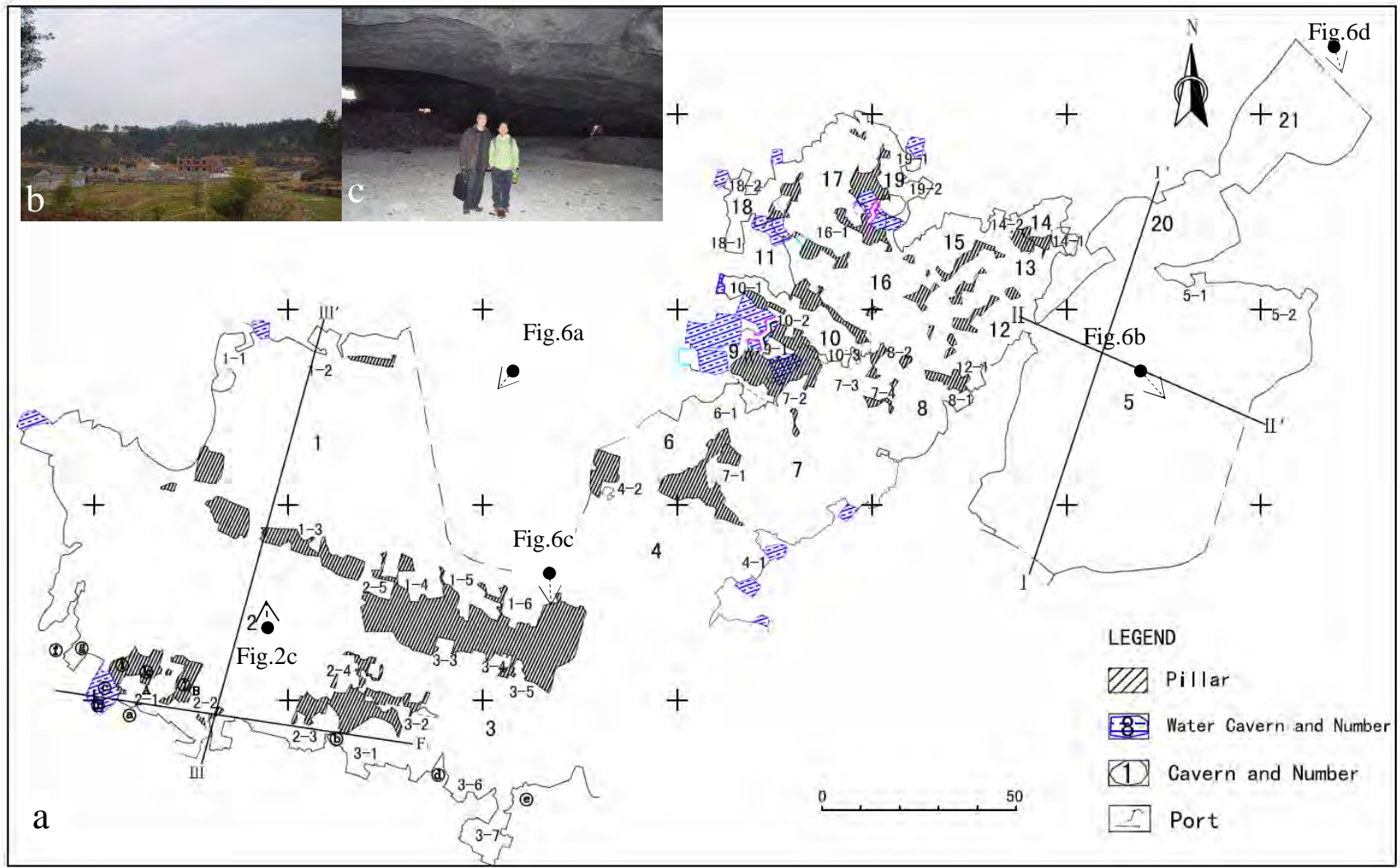

Fig. 2 Layout of the studied 21 caverns at Heidong quarry. a. Plane map of the caverns with pillars in strikes of NW and NE. b. Southward viewing outside of the quarry gate for the subdued Xieshan Hill. c. Northward viewing at No.2 cavern. 
Table 1. Some geodata of ancient large scale caverns with respect to geometry

\begin{tabular}{|c|c|c|c|c|c|c|}
\hline Name & Location & $\begin{array}{c}\text { Cave } \\
\text { number }\end{array}$ & $\begin{array}{l}\text { Size(cavern span } \\
\text { and height) }\end{array}$ & $\begin{array}{l}\text { Original } \\
\text { excavation year }\end{array}$ & $\begin{array}{l}\text { Surrounding } \\
\text { rock }\end{array}$ & Reference \\
\hline $\begin{array}{l}\text { Wieliczka Salt } \\
\text { Mine }\end{array}$ & Wieliczka, Poland & 2040 & $\begin{array}{l}\text { extraction } 7.5^{*} 10^{6} \mathrm{~m}^{3} \text {, } \\
\text { length } 200 \mathrm{~km}\end{array}$ & 13th century & Salt & Zuber et al., (2000) \\
\hline $\begin{array}{l}\text { Bet Guvrin } \\
\text { Caverns }\end{array}$ & Israel & 800 & $\begin{array}{l}\text { Span } 20-40 \mathrm{~m}, \\
\text { cavern height } 15-20 \mathrm{~m} \text {, } \\
\text { cover height } 4 \mathrm{~m}\end{array}$ & 1300 years ago & Chalk $\left(\mathrm{E}_{2}\right)$ & $\begin{array}{l}\text { Tsesarsky et al., } \\
(2000) \text {; } \\
\text { Hatzor et al., (2002) }\end{array}$ \\
\hline Basilica Cistern & Istanbul, Turkey & & $\begin{array}{l}\text { Area } 9800 \mathrm{~m}^{2} \text { (span } 70 \mathrm{~m} \text {, } \\
9 \mathrm{~m} \text { high). } 336 \text { nos. pillars }\end{array}$ & $532 \mathrm{AD}$ & Marble & $\begin{array}{l}\text { http://english. } \\
\text { istanbul.gov.tr }\end{array}$ \\
\hline Longyou Caverns & $\begin{array}{l}\text { Longyou County, } \\
\text { China }\end{array}$ & 25 & $\begin{array}{l}\text { Span } 18-34 \mathrm{~m} \text {, length } 16-43 \mathrm{~m}, \\
\text { cover height } 0.6-21.3 \mathrm{~m}^{*}\end{array}$ & $\begin{array}{l}2000 \text { years ago } \\
\text { (Western Han Dyn.) }\end{array}$ & $\begin{array}{l}\text { Brick red pelitic } \\
\text { siltstone }\left(\mathrm{K}_{2} \mathrm{q}\right)\end{array}$ & Li et al., (2009) \\
\hline $\begin{array}{l}\text { Feifengyan } \\
\text { Caverns }\end{array}$ & $\begin{array}{l}\text { Xianju County, } \\
\text { China }\end{array}$ & $>46$ & $\begin{array}{l}\text { Area } 30000 \mathrm{~m}^{2} \text { Span } 32-43 \mathrm{~m} \text {, } \\
\text { cavern \& cover height } 5-31 \mathrm{~m} \\
\& 23-63 \mathrm{~m}\end{array}$ & $\begin{array}{l}700 \text { years ago } \\
\text { (Song Dyn.) }\end{array}$ & $\begin{array}{l}\text { Gray white } \\
\text { zeolitization } \\
\text { ripple rubble- } \\
\text { bearing vitric } \\
\text { tuff }\left(\mathrm{K}_{2} \mathrm{t}\right)\end{array}$ & Guo (2006) \\
\hline $\begin{array}{l}\text { Shepan Island } \\
\text { Caverns }\end{array}$ & $\begin{array}{l}\text { Sanmen County, } \\
\text { China }\end{array}$ & 1300 & $\begin{array}{l}\text { Area } 37000 \mathrm{~m}^{2} \text {; Span } 20-43 \mathrm{~m}, \\
\text { cover height } 7-30 \mathrm{~m}\end{array}$ & $\begin{array}{l}800 \text { years ago } \\
\text { (Song Dyn.) }\end{array}$ & $\begin{array}{l}\text { Ripple vitric } \\
\text { tuff }\left(\mathrm{J}_{3} \mathrm{~d}\right)\end{array}$ & Zhang (2010) \\
\hline Panlong Caverns & Huangyan, China & $>23$ & Span $30 \mathrm{~m}, 64.3 \mathrm{~m}$ high & $\begin{array}{l}\text { Early than Ming } \\
\text { Dynasty }\end{array}$ & $\begin{array}{l}\text { Ripple rubble- } \\
\text { bearing tuff }\left(\mathrm{J}_{3} \mathrm{z}\right)\end{array}$ & Yang et al., (2007) \\
\hline Heidong Caverns & $\begin{array}{l}\text { Tiantai County, } \\
\text { China }\end{array}$ & 21 & $\begin{array}{l}\text { Area } 24000 \mathrm{~m}^{2} \text { Span } 50-81 \mathrm{~m} \text {, } \\
\text { cavern and cover heights } 5-22 \\
\text { and } 5-40 \mathrm{~m}\end{array}$ & $\begin{array}{l}1413 \text { years ago } \\
\text { (Sui Dyn.) }\end{array}$ & $\begin{array}{l}\text { Gray white ripple } \\
\text { vitric tuff }\left(\mathrm{K}_{2} \mathrm{t}\right)\end{array}$ & This paper \\
\hline Changyu Caverns & Wenling, China & 1314 & $\begin{array}{l}\text { Area } 68000 \mathrm{~m}^{2}(\operatorname{span} 53 \mathrm{~m} \text {, } \\
\text { height } 73.4 \mathrm{~m})\end{array}$ & $\begin{array}{l}1600 \text { years ago } \\
\text { (The northern } \\
\text { and Southern Dyn.) }\end{array}$ & $\begin{array}{l}\text { Light gray } \\
\text { brecciform } \\
\text { tuff }\left(\mathrm{J}_{3} \mathrm{x}\right)\end{array}$ & Yang et al., (2011) \\
\hline
\end{tabular}

* The most shallow cavern is only $0.6 \mathrm{~m}$ underlying. Dyn.-Dynasty.

and polarizing microscope observtion was carried out. The polished thin section is about $0.03 \mathrm{~mm}$ thick.

Uniaxial compression test was completed in rock mechanics laboratories.

Finite element numerical method was adopted for simulation of the DQF excavation induced fracture propagation.

\section{Engineering Geological Conditions}

The Xieshan Hill, which is striking to azimuth 60 with a height difference of $50 \mathrm{~m}$ (from $70 \mathrm{~m}$ to $120 \mathrm{~m}$ above sea level). According to the regional geology, the stratum belongs to Tangshang Group of upper Cretaceous $\left(\mathrm{K}_{2} \mathrm{t}\right)$. Three nearly horizontal layers are exposed

Table 2. General features of the three layers

\begin{tabular}{|c|l|l|c|c|}
\hline Layer & $\begin{array}{l}\text { Observed } \\
\text { thickness }\end{array}$ & Rocks & Weathered & Occurrence \\
\hline 6 & $\begin{array}{l}\text { Very thick } \\
\text { bedding } \\
5-10 \mathrm{~m}\end{array}$ & $\begin{array}{l}\text { slight gray massive } \\
\text { ripple rubble-bearing } \\
\text { vitric tuff }\end{array}$ & fresh & \\
\hline 7 & $0.3-1.0 \mathrm{~m}$ & $\begin{array}{l}\text { purplish red blocky } \\
\text { tuffaceous conglo- } \\
\text { merate-bearing } \\
\text { bearing sandstone }\end{array}$ & slightly & \multirow{2}{*}{$\mathrm{N} 10-24^{\circ} \mathrm{W}}$, \\
\cline { 1 - 3 } & $\begin{array}{l}\text { Very thick } \\
\text { bedding, } \\
5-8 \mathrm{~m}\end{array}$ & $\begin{array}{l}\text { gray purple blocky } \\
\text { ripple vitric tuff }\end{array}$ & slightly & \\
\hline
\end{tabular}

from the top (Layer 8) to the bottom (Layer 6) (Team of Regional Geology Expedition, 1978). The layers 7 and 8 (observed thickness $5-8 \mathrm{~m}$ ) are slightly weathered. Layer 8 is composed of gray purple blocky ripple vitric tuff. The Layer 7 is only $0.3-1.0 \mathrm{~m}$ thick with development of horizontal joints. The rock is weak and fractured as moderately weathered. Layer 7 is composed of purplish red blocky tuffaceous conglomerate. The occurrence of Layer 7 measured at No.5 cavern with the largest span is $\mathrm{N} 10-24^{\circ} \mathrm{W}, \mathrm{NE} \angle 15-28^{\circ}$. Layer 6 is massive or very thick bedding as integrated mass (observed thickness 5-10 $\mathrm{m}$ at different caverns) (Table 2). The joints and fissures are less developed with slightly weathered or jointed. Layer 6 is comprised of slight gray massive ripple rubble-bearing vitric tuff, which is partlly distinguished with slight yellow streaks (Fig.3). The caverns were excavated through the transverse isotropic Layer 6 of $\mathrm{K}_{2} \mathrm{t}$.

The Quzhou-Tiantai Fault (about $250 \mathrm{~km}$ long, extending NEE EW) located at $12 \mathrm{~km}$ south of the Tiantai county town. This fault and few folds were formed at early stage of Yanshan Movement (Team of Regional Geology Expedition, 1978). Their properties are NE Cathaysian structure in a strike of NE dominated by compression discontinuities.

At the No. 2 cavern, the fault $\mathrm{F}_{1}\left(\mathrm{~N} 82^{\circ} \mathrm{W}, \mathrm{SW} \angle 65^{\circ}\right)$ is exposed at its south wall (Fig.2) the gouge is as thick as $0.3-0.4 \mathrm{~m}$ (Fig.4a and $4 \mathrm{~b})$.

Besides, in site survey we measured 85 joints and their occurrence. The rose diagram of the discontinuities with two principal sets $\left(\mathrm{N} 7^{\circ} \mathrm{E}\right.$, $\mathrm{NW} \angle 89^{\circ}$ and $\mathrm{N} 82^{\circ} \mathrm{W}, \mathrm{SW} \angle 50^{\circ}$ ) is shown in Fig. 5 a. Meanwhile, most of the dip angles are over $50^{\circ}$, dominated by $80^{\circ}-90^{\circ}$ (Fig. $5 \mathrm{~b}$ ). 

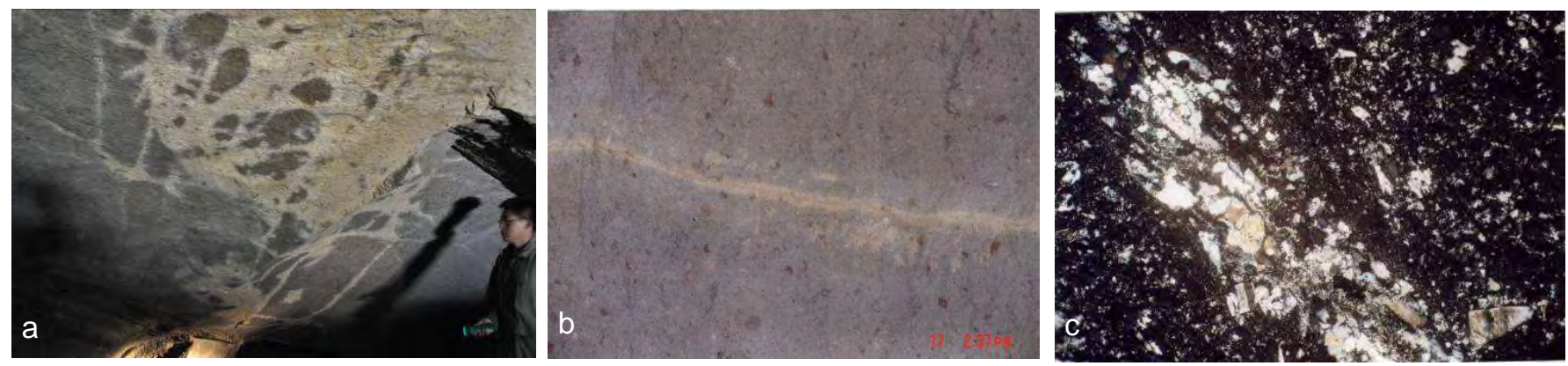

Fig.3. Slight yellow streaks found at Heidong quarry. (a) As groups in immediate roof of Layer 6 tuffs obvious found at Nos. 6 and 7 caverns. (b) Single strip at side wall of No.5 cavern. (c) Microscopic texture of the streaks in thin section.

\section{Results}

\section{Time of original quarry}

Near Heidong quarry, there is Shangqiu village (Fig.1b) which owns a family-preserved ancient book named "A genealogy of surname Qiu at Tiantai Mountain". In this book, there is a sentence "The nearby Xieshan Hill was excavated to be hollow in Shenzhong years of the North Song Dynasty (1068-1077AD)". In other words, the Heidong quarry was already a large scale ancient underground quarry for excavation of flagstones at North Song Dynasty, more than 1000 years ago.

At Tatou Temple $13 \mathrm{~km}$ north (Fig.1b), there exists a tablet weighing $1500 \mathrm{~kg}$ made of tuffs set up during Tang Dynasty (811AD). The Tatou Temple sits above red layers of Cretaceous series, therefore, the extracted tuffs for the tablet was certainly from other sites. By comparison, it is clear that the close proximity quarry is the Heidong Cavern. Other sites, like the Meiyuan open-pit quarry within the jurisdiction of Ningbo city is located $100 \mathrm{~km}$ north, the Changyu Caverns at Wenling is $105 \mathrm{~km}$ south (Fig.1a). The flagstone of the Tang tablet is proved to be extracted in Heidong quarry because the rocks are the same as slight gray massive ripple rubble-bearing vitric tuffs. That means, it was quarried from the Layer 6 of $\mathrm{K}_{2}$ t. Moreover, there are 3 slight yellow narrow streaks found in the Tang tablet, which is commonly seen at Nos. 1, 3, 5, 6 and 7 caverns of the Heidong quarry (Fig.3a and 3b). Microscopic observation reveals that the yellow streak is a complex of fine-grained albite, biotite and calcite (Fig.3c). This means that the original excavation of Heidong quarry is earlier than $811 \mathrm{AD}$, about 1200 years ago.

At Guoqing Temple (Sui Dynasty) $6 \mathrm{~km}$ north (Fig.1b), the slight yellow streaks are also found at an ancient Buddha tablet. That tablet was carved in Sui Dynasty (598 AD). It can be inferred that the Heidong quarry was originally excavated no later than 1413 yrs ago, so that, these caverns can be named as millennium quarry caverns.

\section{Trial adits and cavern geometry}

At the foot of Xieshan Hill, several trial adits filled with jadegreen waters while some trial pits kept with steep cut slopes can be identified by characteristic chisel marks and dark patina (Fig. $4 \mathrm{c}$ and $4 d)$. They are believed to be extensively exploitated as a trial approach to excessive enlargement of individual caverns extracted in the massive and homogeneous gray tuffs, while avoid or escape from fractured or strongly weathered rocks with signs indicative of distress.

On the basis of field survey, fault $F_{1}$ at points $A$ and $B$ within branch caverns 2-1 and 2-2 (Fig.2a) seriously caused the precarious stability of southern lateral wall of No.2 cavern, which was well known by the ancient craftsmen. They applied two entirely warranted approaches to deal with it. Firstly, they excavated normal to the fault with smaller area of working face. Secondly, they left more pillar walls along the southern extremes as for smaller scale branch caverns (Fig.4a and 4b). They tried advancement while working in close proximity to the fault. Till now this kind of observation method is generally preferred in rock engineering design and excavation (Stille and Palmstrom, 2003).

The 3 layers from bottom to top are Layers 6, 7 and 8 (Team of Regional Geology Expedition, 1978), whose engineering geological conditions belonged to most favorable, poor and moderate, respectively. Ancients focused on the integrated and competent Layer 6 as the main quarrying rocks. As immediate roof, the thinnest, fragile and anistropic layer 7 (0.3-1.0 m thick in general) was almost completely excavated or kept at the abutments in case of potential collapse (Fig.6d). And Layer 8 was also well quarried except of the dominant Layer 6 in shallow caverns. The measure of dome roof was adopted in large span caverns such as Nos.2 and 5.

Three cross sections, I-I' and II-II' of No.5, III-III' of Nos. 1 and 2 caverns drawn from Fig.2, are shown in Fig.7. According to field
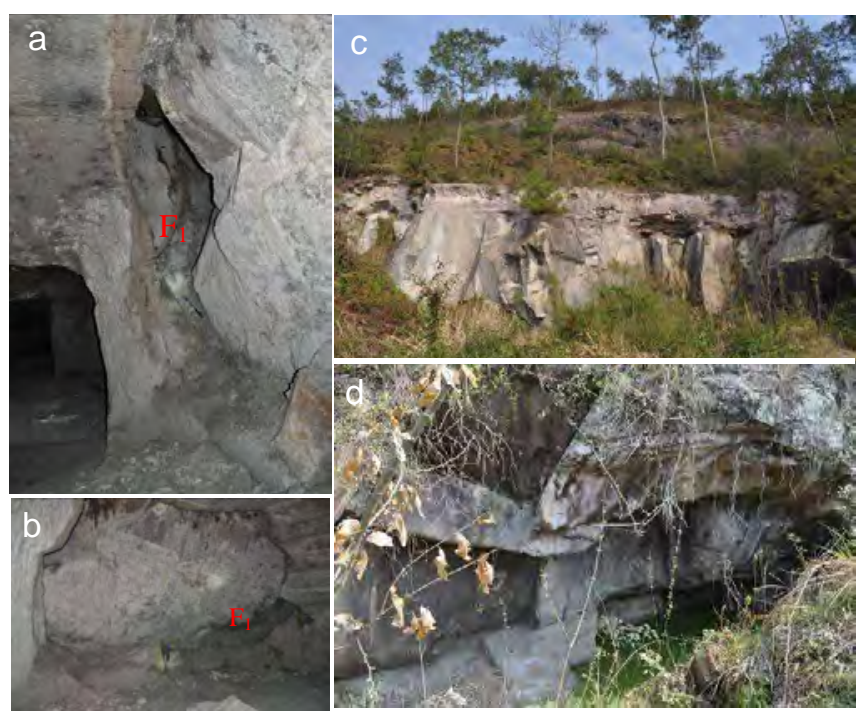

Figure 4. Observation approach in excavation at the Heidong quarrying. The blue geological hammer with a hand length of $35 \mathrm{~cm}$ is presented for scaling. a, Cut through normally to the fault $F_{1}$ with a smaller diameter. $b$, When $F_{I}$ was encountered the excavation was deliberately modified or stopped. c, Trial pits with steep cut cliffs. $d$, Trial adits filled with water at slope feet. 


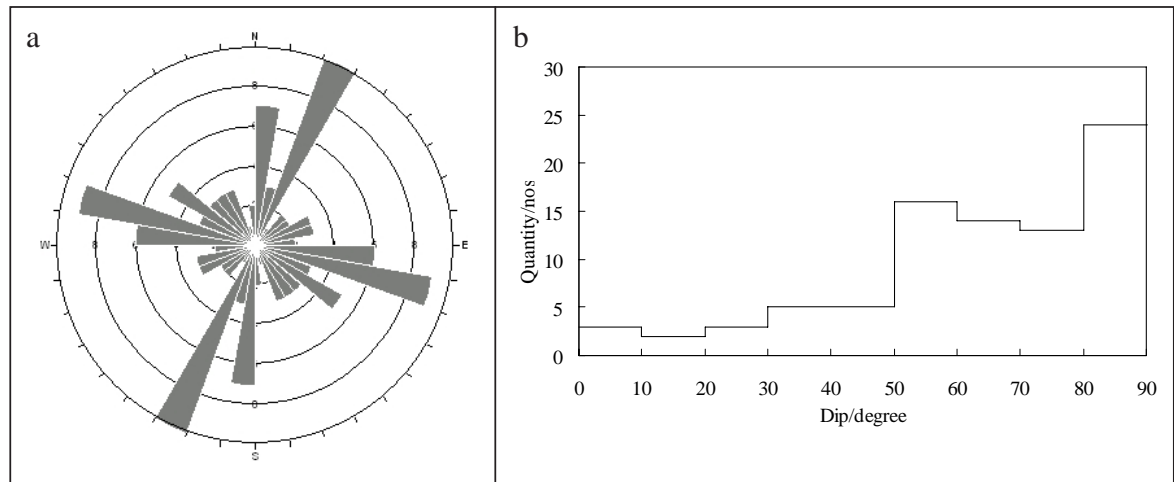

Figure 5 Distribution features of the discontinuities. a. Rose diagram of discontinuity strikes; b. Bar diagram of discontinuity dip vs frequency.

measurement, it is known that the largest span is $81 \mathrm{~m}$. And the common wall is 4-6 $\mathrm{m}$ thick, which takes account of $3.4-5.1 \%$ of the combined span $117 \mathrm{~m}$ of Nos.1 and 2. The two caverns are parallel with each other with spans of $60 \mathrm{~m}$ and $53 \mathrm{~m}$, respectively, which are rarely seen up to now (as cross section III-III' in Figs. 2c, 6a and 7c). Generally as dome roof, the span of the No.5 cavern is $62 \mathrm{~m}$ in eastwest, and $81 \mathrm{~m}$ in north-south, respectively (Figs.6b,7a,7b). According to updated referential data, it is the largest span worldwide within unsupported quarrying caverns (Barton et al., 1994; Broch et al., 1996). Additionally, the cover height of No.5 is only 5-20 m, no more than 0.25 times of the span, which makes the miraculous stability over 1000 years.

\section{Mechanical strength and rock mass quality}

The mechanical test results of the sampled cylinder restrieved from intact rocks are listed in Table 3. They represent the response of virgin material unaffected by ongoing failure in the process of

Table 3. Mechanical lab test results of intact rocks from Heidong quarry caverns

\begin{tabular}{|c|c|c|c|c|c|c|c|}
\hline Layer & $\begin{array}{c}\gamma \\
\left(\mathrm{g} / \mathrm{cm}^{3}\right)\end{array}$ & $\begin{array}{c}\mathrm{E} \\
(\mathrm{GPa})\end{array}$ & $\mu$ & $\begin{array}{c}\mathrm{UCS} \\
(\mathrm{MPa})\end{array}$ & $\begin{array}{c}\mathrm{C} \\
(\mathrm{MPa})\end{array}$ & $\begin{array}{c}\Phi \\
\left({ }^{\circ}\right)\end{array}$ & $\begin{array}{c}\mathrm{Rt} \\
(\mathrm{MPa})\end{array}$ \\
\hline 6 & 1.932 & 13.60 & 0.27 & 50.00 & 7.80 & 55.70 & 4.8 \\
7 & 2.361 & 11.65 & 0.30 & 22.44 & 4.47 & 38.09 & 1.1 \\
8 & 2.279 & 12.67 & 0.30 & 37.49 & 11.12 & 29.81 & 2.9 \\
\hline
\end{tabular}

$\gamma$ - Bulk dry density, E-elastic modulus, $\mu$ - Poisson's ratio,UCS -Uniaxial compressive strength, C - cohesive force, $\Phi$ - Frictional angle, Rt - Brazilian tensile strength.

quarrying. From the uniaxial compressive strength (UCS), it is known the intact rocks at Layers 6 and 8 belong to low to moderate strength, while intact rocks at Layer 7 belongs to very low strength (Stille and
Palmstrom, 2003). According to corresponding standards and specifications (Brown, 1981; Ministry of Water Resource, PRC, 1995), the former two belongs to harder rock, while the latter one to softer rock.

The discontinuities at Heidong quarry are primarily clean joints with little or no infilling materials. A total of 85 discontinuities were mapped in the studied complex. Many joints transect the caverns and exhibit trace lengths of tens of meters.

Rock mass quality classification method, e.g. Q (Barton et al., 1974) and RMR (Bieniawski, 1976) are widely accepted. These two methods have been adopted in the current study, using the site investigation and mechanical test data described above. The results for RMR and Q classifications are listed in Tables 4 and 5, respectively. The RMR values are 77, 36 and 63 for the three layers, belonging to II, IV and II grades, respectively. According to these values, the caverns in Layer 6 up to $10 \mathrm{~m}$ span would be expected to sustain a stand up time of 1 year.

If the bulk density and buried depth for the three layers as $30 \mathrm{~m}$ for Layer 6 and $20 \mathrm{~m}$ for the other two layers then, the maximum tangential stresses are $600 \mathrm{kPa}$ and $450 \mathrm{kPa}$, respectively. The SRF parameter which incorporates the strength/stress ratio $\left(\sigma_{\mathrm{c}} / \sigma_{1}\right)$ can be returned (Barton et al., 1974). The Q value of the single Layer 6 with massive tuff is the most favorite only within this layer. If the Layers 7 and 8 are considered together, the rock mass quality will be decreased with smaller Q values (roughly $\mathrm{Q}=10-50$ ).

According to Barton et al., (1974), the unsupported span or height/ESR (ESR is Excavation Support Ratio) is about 10. For temporal and permanent mine openings, the ESR $=3-5$, and 1.6, respectively. The corresponding span is $30-50 \mathrm{~m}$, and $16 \mathrm{~m}$, respectively. Even the maximum $50 \mathrm{~m}$ span of temporal mine openings is far fewer than the actual $81 \mathrm{~m}$ span of the No.5 cavern in integrated Layer 6.

From the Chinese current specifications (Ministry of Water Resources, PRC, 1995) it is clear that the most preferred surrounding rocks of Layer 6 belong to class I with weighted mean value of $\mathrm{Q}=40-1000$. For this kind of rocks, spans without supports are expected to be less than $15 \mathrm{~m}$ so as to keep them stable for long time (SBMI, 2001). Here, in Heidong quarry caverns, the Q is less than 51 , the unsupported largest span is less than $50 \mathrm{~m}$ as temporal mine openings, or $15 \mathrm{~m}$ as permanent mine openings (Barton, 2002), but it showed up to be $81 \mathrm{~m}$ and kept stable for about 1400 years. This indicates the huge differences between current knowledge and actual stable conditions with respect to unsupported stable time.
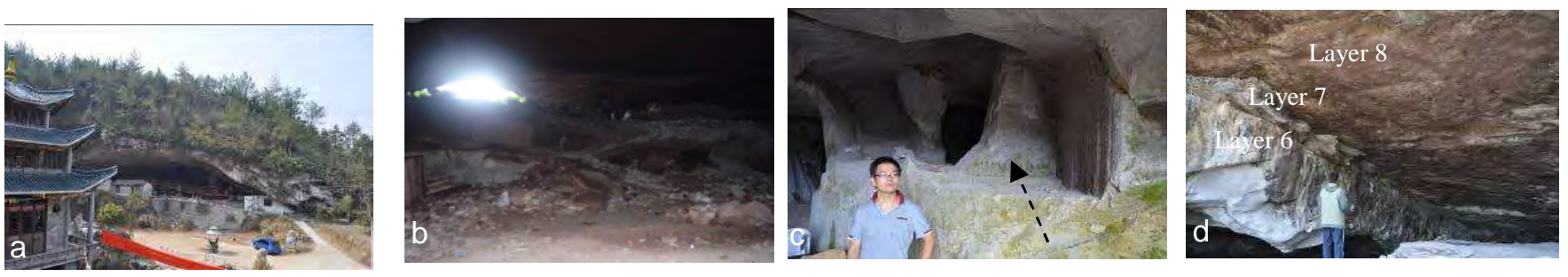

Fig. 6. Plates showing structure of caverns at Heidong quarry (For locations, see Fig 2a). a. SW viewing outside of No.1 cavern. b. SE viewing in No.5 cavern. $c$. The holes at bottom of one side wall at branch cavern 2-3. $d$. The three slightly dipping layers (location: port of No.21 cavern). 
Table 4. RMR classification scheme for the three layers at Heidong quarrying caverns

\begin{tabular}{|c|c|c|c|c|c|c|}
\hline & \multicolumn{2}{|l|}{ Layer 6} & \multicolumn{2}{|l|}{ Layer 7} & \multicolumn{2}{|l|}{ Layer 8} \\
\hline & Index & Rating & Index & Rating & Index & Rating \\
\hline UCS/MPa & 50 & 7 & 22.44 & 2 & 37.49 & 4 \\
\hline RQD/\% & 90 & 20 & 60 & 8 & 80 & 17 \\
\hline Spacing/cm & $>200$ & 25 & 60 & 10 & $>200$ & 20 \\
\hline $\begin{array}{l}\text { Condition of } \\
\text { discontinuities }\end{array}$ & $\begin{array}{l}\text { Slightly rough surface, } \\
\text { separation }<1 \mathrm{~mm}\end{array}$ & 20 & $\begin{array}{l}\text { Slightly rough surface, } \\
\text { separation }<1 \mathrm{~mm} \text {, } \\
\text { with soft fillings }\end{array}$ & 15 & $\begin{array}{l}\text { Slightly rough surface, } \\
\text { separation }<1 \mathrm{~mm}\end{array}$ & 18 \\
\hline $\begin{array}{l}\text { Groundwater } \\
\text { condition }\end{array}$ & dry & 10 & wet & 7 & dry & 10 \\
\hline $\begin{array}{l}\text { Orientation of } \\
\text { discontinuities } \\
\text { RMR (grade) }\end{array}$ & 77 (II) & -5 & 36 (IV) & -6 & 63 (II) & -6 \\
\hline $\begin{array}{l}\text { Stand up time } \\
(\text { span } \mathrm{m})\end{array}$ & $1 \mathrm{a}(10 \mathrm{~m})$ & & $10 \mathrm{~h}(2.5 \mathrm{~m})$ & & 1a $(10 \mathrm{~m})$ & \\
\hline
\end{tabular}

Table 5 Q classification for the three layers at Heidong quarrying caverns

\begin{tabular}{|c|c|c|c|c|c|c|}
\hline & \multicolumn{2}{|c|}{ Layer 6} & \multicolumn{2}{|l|}{ Layer 7} & \multicolumn{2}{|c|}{ Layer 8} \\
\hline & Index & Rating & Index & Rating & Index & Rating \\
\hline RQD & Excellent & 95 & General & 60 & Good & 80 \\
\hline Number of joint sets (Jn) & 2 & 4 & 4 & 12 & 3 & 9 \\
\hline Roughness (Jr) & noncontinuous & 4 & Smooth undulating & 3 & Smooth undulating & 3 \\
\hline Degree of alteration (Ja) & Close contact & 0.75 & Unaltered & 1 & Unaltered & 0.75 \\
\hline Water inflow (Jw) & Dry excavation & 1 & Dry excavation & 1 & Dry excavation & 1 \\
\hline $\operatorname{SRF}\left(\sigma_{c} / \sigma_{1}\right)$ & $50 / 0.6=83$ & 2.5 & $22.44 / 0.45=50$ & 5 & $37.49 / 0.45=83$ & 2.5 \\
\hline Q (grade) & \multicolumn{2}{|c|}{51 (Very good) } & \multicolumn{2}{|l|}{3 (Poor) } & \multicolumn{2}{|c|}{14.2 (Good) } \\
\hline
\end{tabular}

\section{Quarrying mechanism}

In caverns we found lots of holes left in waste rocks and rows of digging holes on the side walls (Fig.6c). It is inferred that the thickness of flagstones is $60-80 \mathrm{~mm}$. Field survey and enquiry with local craftsmen clarify that the ancient craftsmen used short chisel and hammer to quarry flagstones just like splitting rocky sheets in vertical side walls. Firstly, the designed size of the flagstone was circled in a vertical side wall, then three grooves which are 70-90 mm, deeper than flagstone thickness, are made carefully along its three boundaries, top, left and right. After that, a row of small digging holes with both the diameter and intervals of $30 \mathrm{~mm}$ are bored in its bottom. All the holes dipped $20-30^{\circ}$ upward to make it easy to get the flagstone with uneven margins. Here the technique initially adopted by ancestors is named as Digging Holes for Quarrying Vertical Flagstone (DQF).

Further, theoretical research indicates that the above DQF is concordant with the principle of fracture mechanics (Whittaker et al., 1992). According to geometric conditions revealed in Fig.8a and 8b, a representative digging hole is shown in detail in Fig.8c, the quarrying mechanism can be inferred. Firstly, the short chisel was penetrated into digging holes at its bottom boundary, and using hammer it is struck in sequence. Continuous striking make the holes fractured and tended to be jointed one by one. Then after some circular striking, the jointed cracks developed upward dissecting the left, right and reaching the top boundary grooves. At last, the stone is decoupled from surrounding rocks as a flagstone. In some cases, the mostly vertical dipping joints are used instead of lateral free grooves in quarrying flagstones. And the overall strikes of side walls are parallel with the two sets of joints (Fig.5a). Obviously, using these joints has advantages of saving quarrying time, and lessening rate of stripping with quarrying to increase the efficiency.

Here it should be noted that the quarried flagstone behaves half of a row of digging holes at its bottom boundary, while the other half is kept on walls of the surrounding rocks. So the craftsmen cut down the left half of holes adhered in flagstones, then put them within caverns as waste rocks. Figure 8a just shows a waste rock sample. While Fig.6c shows the other half of holes as a row left in side walls. Obviously, Fig. 8 certifies the above inference on excavation mechanism at Heidong quarry.

Besides, the fracturing mechanism is clarified by using 2-D numerical simulation of the finite element method (FEM) (Wang and $\mathrm{Li}, 2008$ ), which clearly indicated that the crack originated at bottom boundary, developed to grooves at top boundary, thus one flagstone was well obtained.

\section{Volume of waste rocks}

The ancestors stacked waste rocks inside and the refuse dump reached $9.4 \mathrm{~m}$ thick at No.5 cavern, $6.8 \mathrm{~m}$ at Nos. 1 and 2 caverns. In fact, all the 21 caverns were used for stacking waste rocks. If the average thickness $3.5 \mathrm{~m}$ is taken into account, the bulky volume of waste rocks is about $40,000-84,000 \mathrm{~m}^{3}$ within the quarry caverns.

The waste rocks inside played a key role of providing confinement and support for limiting the amount of convergence of the rock mass (Tesarik et al., 2009. This measure was also environment-friendly (Butzer, and Harris, 2007). The idea of preserving ecological environment 1400 years ago is surprisingly admirable.

It is understood that there are three advantages to adopt this approach of disposal waste rocks from quarrying extraction within caverns. Firstly, the cost of taking these waste rocks outside of caverns was saved. Secondly, the stacked waste rocks support stability of side walls, even the large scale of caverns because of the decreasing cavern height, as situations of largest span and thinning common walls. Thirdly, the waste rocks kept within caverns prevented a fertile 
a
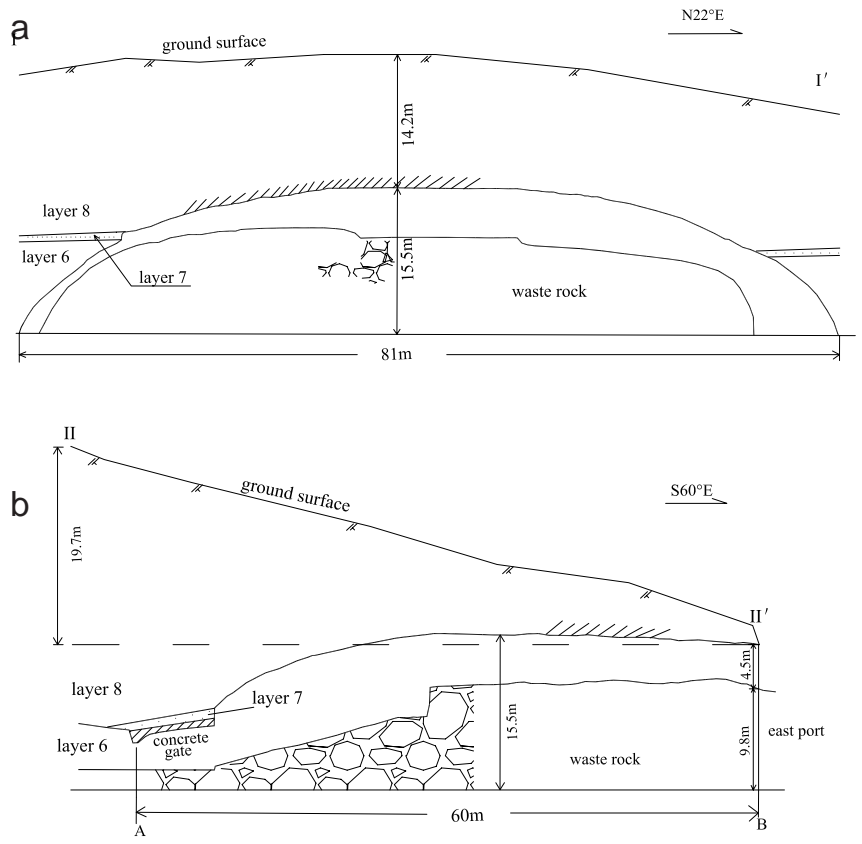

C

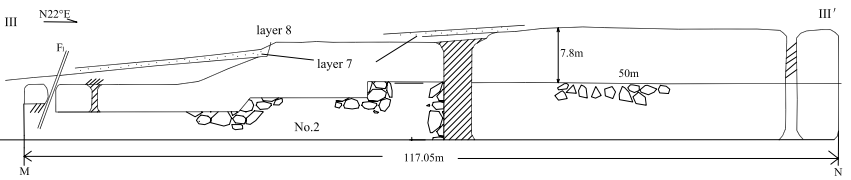

Figure 7 Cross sections of the caverns (For their locations, see Fig.2a). a. Section I-I' along north-south with a span of $81 \mathrm{~m}$ at No.5. b. Section II-II' along east-west with a length of $62 \mathrm{~m}$ at No.5. c. Section of the common side wall between Nos. 1 and 2 caverns.

farmland outside of caverns from burying, thus preserving ecological system.

\section{Discussion}

The smart quarrying measure and geometric align led to the surprising long-term stability of Heidong quarry caverns. The caverns were quarried by DQF, rather than blasting and casting technique commonly adopted at present for quick excavation, which results in a noticeable excavation damaged zone (EDZ) (Shen and Barton, 1997) and causes most unstability in surrounding rocks. DQF was special in ancient times, slow but safe. Here, the equipment is a limiting
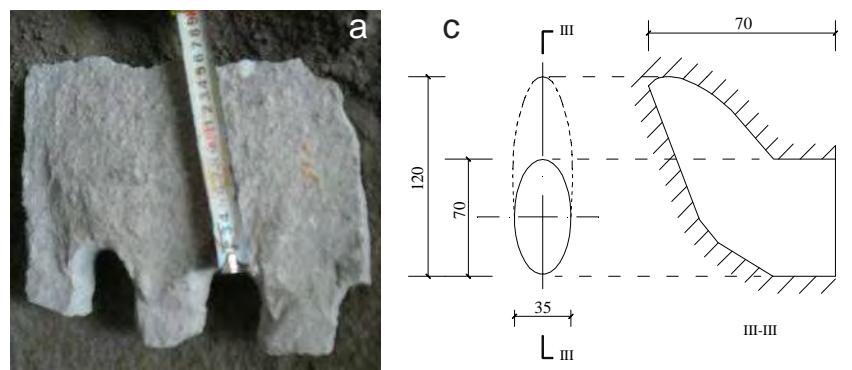

b

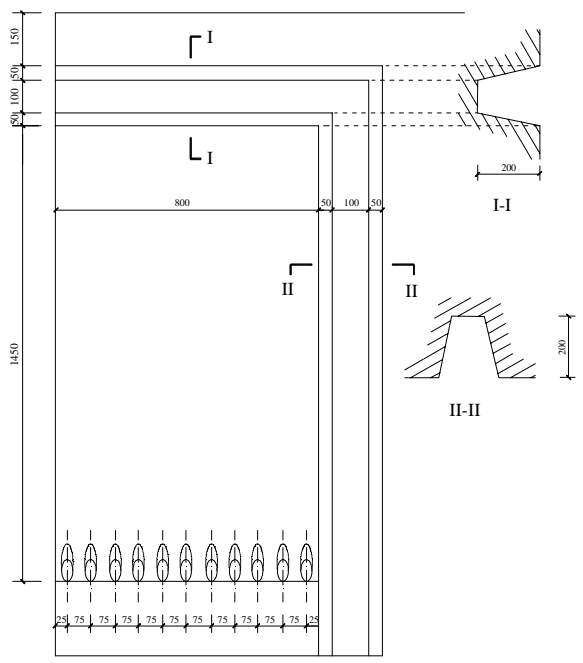

Figure 8 Small digging holes left in Heidong quarrying site. The common side intervals of adjacent holes is 30mm. Unit:mm) a. One waste rock specimen left at caverns with a half of digging holes. b. Plane map showing a row of small digging holes bored at side walls. $c$. Plane and section showing small digging holes

factor, but this kind of construction-oriented approach was successfully adopted (Sagefors and Daerga, 1996). Blasting and casting technique is fast but effective measures must be taken into account in order to eliminate the negative affects on surrounding rocks. Electric saw is widely used today for industrial quarrying which mostly gets only smaller stones and costs lots of energy though a little EDZ (Fig.9). The comparison reminds us how to strike a balance among efficiency, safety and environment-friendly of underground rock engineering. The Heidong caverns keeping long term stability provide a distinct analogical and extrapolative model.

In a word, the Heidong caverns with a largest span cavern was
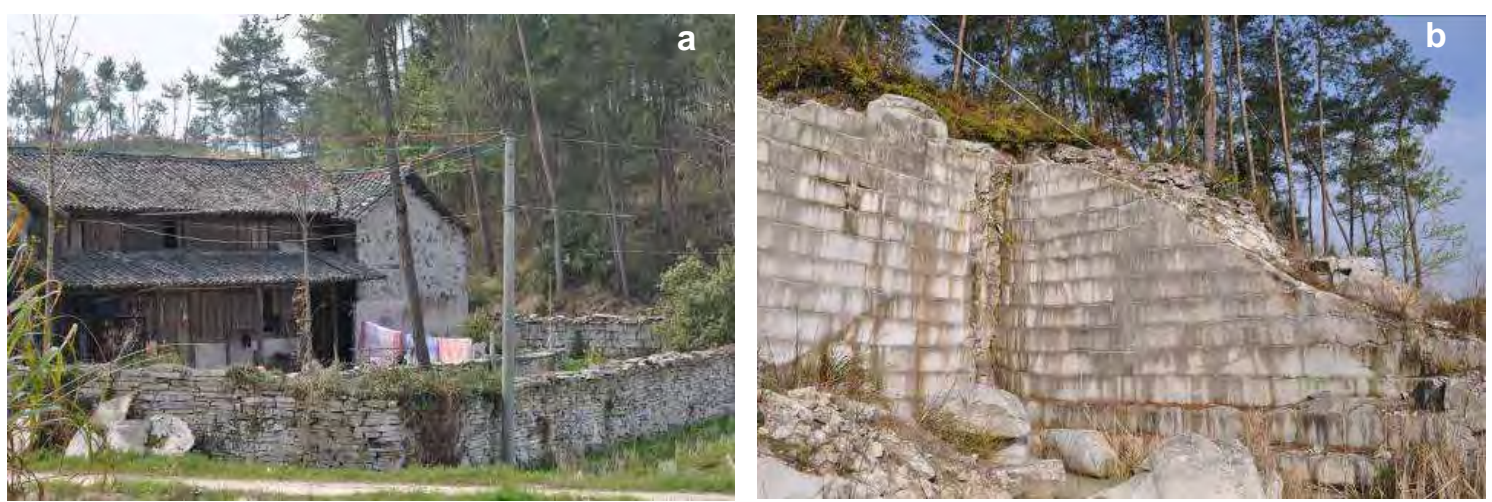

Figure 9 Quarrying stones for building houses in history and adopted techniques at present. a, Historical house building in cut flagstones. b, Quarrying cliff with traces of electric saws. 
originally excavated over 1400 years before at background of the Tiantai Sect. Thus, it can be regarded as one important rocky cultural relic (Fig.1), which is comparable to the Wieliczka salt mine as the first batch of world cultural heritage sites (http://en.wikipedia.org/ wiki/Beit_Guvrin_National_Park).

\section{Conclusions}

The Heidong quarry caverns, comprises of 21 in an area of 24,000 $\mathrm{m}^{2}$, with a largest unsupported span of $81 \mathrm{~m}$. The volume of disposal waste rocks is about $40,000-84,000 \mathrm{~m}^{3}$ within the quarry caverns. The rock mass quality of massive tuffs in Layer 6 is most favorable with high value of $\mathrm{RMR}=77$, and $\mathrm{Q}=51$. The relatively poor quality of tuffaceous conglomerate-bearing sandstones of Layer 7 makes the quarrying site laid under Xieshan Hill be transverse isotropy and the quality decreases as a whole.

The 1400-year old well-kept $81 \mathrm{~m}$ span cavern at Tiantai County in south China is far beyond the $50 \mathrm{~m}$ expectation of the current rock engineering specifications, just because of its unique quarrying technique DQF with little excavation disturbance, by adopting systematic measures constituted of geometric dome roof, trial adits for massive tuff, and inside disposal of waste rocks for cavern supporting.

The ancient quarrying achievement marks a high level in complex natural conditions with manpower. These results are positive to extend our knowledge on category design of cavern scale and stability assessment, and light inspiration for resolution of the conflict between quick excavation with blasting and intensive EDZ in surrounding rocks.

\section{Acknowledgements}

We appreciate financial support by the State Key Laboratory of Geohazard Prevention and Geoenvironment Protection (SKLGP2011K007), Chengdu University of Technology, the Key Research Program of the Chinese Academy of Sciences (KZZD-EW05-02), and by the National Natural Science Foundation of China (NSFC) (Nos. 40972198, 41172269). The support is also from the Chinese Special Funds for Major State Basic Research Project under Grant No. 2010CB732001. Help provided by Master Chang Shen, Long Fu of Heidong CiEn Temple, and Mr. He Wantong during field investigations is thankfully acknowledged. We thank revision suggestions from Prof. S.J. Wang, Dr. Rafig Azzam, and an anonymous reviewer.

\section{References}

Aubertin, M., Li, L., and Simon, R., 2000, A multiaxial stress criterion for short- and long-term strength of isotropic rock media. International Journal Rock Mechanics and Mineral Science, v. 37, pp. 1169-1193.

Barton, N., 2002, Some new Q-value correlations to assist in site characterisation and tunnel design. International Journal Rock Mechanics and Minernal Science, v. 39, pp. 185-216.

Barton, N.R., Lien, R., and Lunde, J., 1974, Engineering classification of rock masses for the design of tunnel support. Rock Mechanics, v. 6, pp. 189-236.

Barton, N., et al., 1994, Predicted and measured performance of the $62 \mathrm{~m}$ span Norwegian Olympic Ice Hockey Cavern at Gjøvik. International Journal Rock Mechanics and Mineral Science \& Geomech. Abstracts, v. 31, pp. 617-641

Bieniawski, Z.T., 1976, Engineering classification of jointed rock masses. Transactions South African Institute of Mining and Metallurgy, v. 74, pp. 335-344

Broch, Einar, Myrvang, Arne M. and Stjern, Gisle, 1996, Support of large rock caverns in Norway. Tunnel and. Underground Space Technology, v. 11 , pp. 11-19.

Brown, E.T., 1981, Rock characterization, testing method and monitoring. ISRM Suggested Methods. Pergamon Press, Oxford.

Butzer, Karl, W. and Harris, Sarah, E., 2007, Geoarchaeological approaches to the environmental history of Cyprus: explication and critical evaluation. Journal Archaeological Science, v. 34, pp. 1932-1952.

Guo, G.M., 2006, Engineering highlights and protection problems of Longwang Hill large scale quarry at Xianju County. Institute of Geology and Geophysics, Chinese Academy of Sciences (Ph.D. Thesis,).

Hatzor, Y.H., Talesnick, M. and Tsesarsky, M., 2002, Continuous and discontinuous stability analysis of the bell-shaped caverns at Bet Guvrin, Israel. International Journal Rock Mechanics and Mineral Science, v. 39, pp. 867-886.

Hatzor, Y.H., Wainshtein, I. and Mazor, D.B., 2010, Stability of shallow karstic caverns in blocky rock masses. International Journal Rock Mechanics and Mineral Science, v. 47, pp. 1289-1303.

Li, L.H., Yang, Z.F., Yue, Z.Q. and Zhang, L.Q., 2009, Engineering geological characteristics, failure modes and protective measures of Longyou rock caverns of 2000 years old. Tunnel and Underground Space Technology, v. 24, pp. 190-207.

Ministry of Water Resources of the People's Republic of China, 1995, Standard for engineering classification of rock masses (GB50218-94) (China Planning Publishing House, Beijing).

News and Views, 1930, Nature, v. 126, pp. 320-324.

Sagefors, I. and Daerga, P.A., 1996, An excavation method for large vertical cylindrical caverns. Tunnel and Underground Space Technology, v. 11, pp. 279-285.

SBMI (State Bureau of Metallurgical Industry) 2001, Specifications for boltshotcrete support (GB50086-2001) (China Planning Publishing House, 2001).

Shen, B. and Barton, N., 1997, The disturbed zone around tunnels in jointed rock masses. International Journal Rock Mechanics and Mineral Science v. 34 , pp. 117-125.

Stille, H., and Palmstrom, A., 2003, Rock mass classification as a tool in rock engineering. Tunnel and Underground Space Technology, v. 18, pp.331-345.

Team of Regional Geology Expedition, Bureau of Zhejiang Geology. Expedition report of regional geology (Xianju Sheet, 1:200,000) (Hangzhou, 1978)

Tesarik, D.R., Seymour, J.B. and Yanske, T.R., 2009, Long-term stability of a backfilled room-and-pillar test section at the Buick Mine, Missouri, USA. International Journal Rock Mechanics and Mineral Science, v. 46, pp. 1182-1196.

Tsesarsky, M., Hatzor, Y.H., and Talesnick, M.L., 2000, The stability of ancient bell-shaped caverns at the Bet Guvrin National Park-a comprehensive geomechanical study. Isr. Journal of Earth Science, v. 49, pp. 81-102.

Wang, S.J., Yang, Z.F. and Liu, Z.H., 1984, Stability analysis on underground engineering rock masses. Science Press, Beijing.

Wang, Z.Y., and Li, Y.P., 2008, Rheological theory and numerical simulation of rock mass. Science Press, Beijing.

Whittaker, B.N., Singh, R.N., and Sun, G.X., 1992, Rock fracture mechanicsprinciples, design and applications. Elsevier Science Publishers B.V., The Netherlands.

Yang, Z.F., Li, L.H., Pan, W., Lu, M. and Zheng, J., 2003, Discussions about large-scale ancient underground engineering. Science Technology and Engineering, v. 3, pp. 464-466.

Yang, Z.F., et al., 2007, Scientific discoveries of Jinxiu-Huangyan Panlong ancient underground cave group and preliminary analyses. Journal of Engineering Geology, v. 15, pp. 322-327.

Yang, Z.F., Guo, G.M., and Zhang, L.Q., 2011, Scientific and technology concerns on large scale ancient Feifeng Quarry at Xianju County and long term preservation. Science Press, Beijing.

Zhang, Z.J., 2010, Engineering geomechanics problem of large-scale ancient underground quarry of Shepan Island in Sanmen County of Zhejiang Province. Institute of Geology and Geophysics, Chinese Academy of Sciences (Ph.D. Thesis).

Zuber, A., Grabczak, J., and Garlicki, A., 2000, Catastrophic and dangerous inflows to salt mine in Poland as related to the origin of water determined by isotope methods. Environmental Geology, v. 39, pp. 229-311. 